スでまをし、エ

三同始つ問 不

テ様ま緻題二

イのつ密状 シ

研傾たな況テ

究向ば研のイ

$$
\text { 緒 }
$$

のがか究記研

なありが述究

かる。の否には、言

はし本し 始差

一かだてし別

般しけいたや

理なでるも偏

論がなのの見

とらく豈多を

て日膨態く敵

広本大で理す

認比研る論る

知卞究。的と

され蓄工背い

れば積 ス景う

でをま算

るメつテ証 意

もりア1的識

の力メ研なが

がのリ究調先

多工力查行

でう二に的状少

るテの稿う継肪り

がイモ⿱ 亿 はで承大と

本・ルのラつく存

論工を第 ス 異在

にン提一で生な专

入ク示歩あかるる。

るとしと前イてして早っ

にブいてといにメ

論る、沙くどリ

こ它国的ここ力

れい内スうとまの

らう植二まがで一

の四民シでで応般

理つ地テもき用理

論の論イなれで論

の理六といばきを

出論分階

発を割層

点総 労 構

と括 働 造

もし市と

なよ場の閔でテ

てと・係永るを

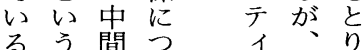

古試㝊い研発ま

典みイて究展く
夕造に社く。に

ン関似の国論稿

に連の中国をで

分を階間植唱は

加中層位植え

れ心構に地る

るに造適地形ず

ど実を行展 メ

を奛!現得お開り

らし得王びてに

かたるス分きお

に。こ二分たけ

し最とッ割たる

た後をク学ア古

に示集働 メ典

諸唆団市り的

理すを場力工

論る分論に ス

の。析抒三

総紙のは、けシ

括幅対社るテ

のの象社工イ

た制と会ス理

め限し宁二論

図もた下シを

式あこ層テ時

华り、工部、代

を試周クと論景

み辺レどのも

、的人まな若

エなブらか午

ス議論ざで考

二論論るも慮

ツはは得忠し

集慧移な的?

団し民华 い紹

の理社工位介

占論会 不置す

め肉学る。

る核部”占。

層なも集てに

的っホ立ている

置いトר四れ

はる社中つら

工会間の古

単 $ᄌ$ ₹ 理 典

二 三 令溣的

でッジノに工

はクヨリつス

な集りテいニ

く団ティてシ

複とイ論論テ

数階社嵒じイ

の層会はて 理

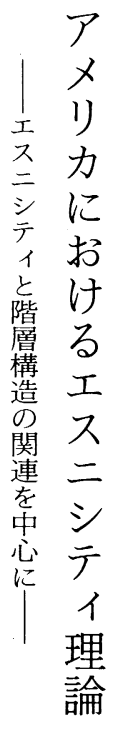

堤

要 
位意が、前心伝意化の教あクへシイえど社

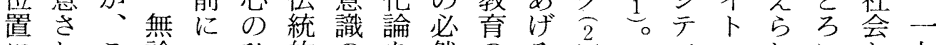

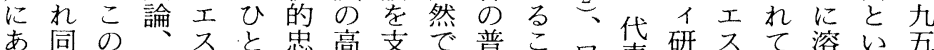

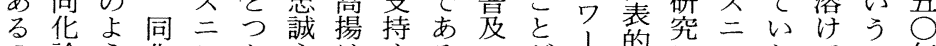

の論う化シと心はする・がス的にッたて学古古

はをなやテしを労ると識でス学おク。ひる代唺イ

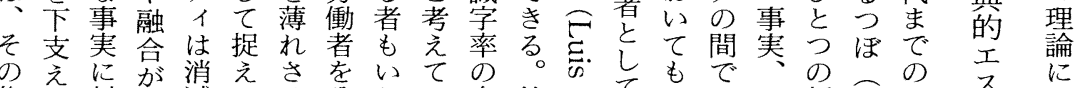

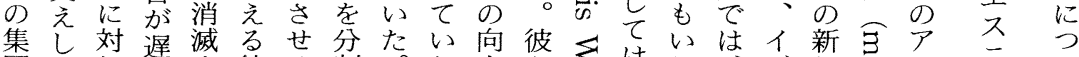

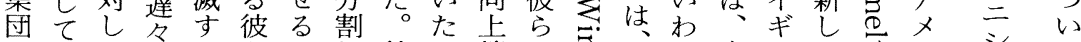

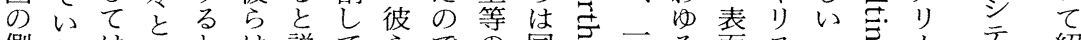

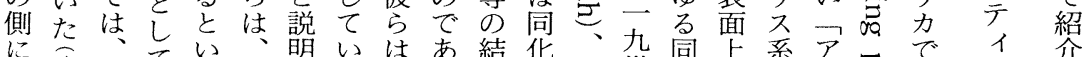

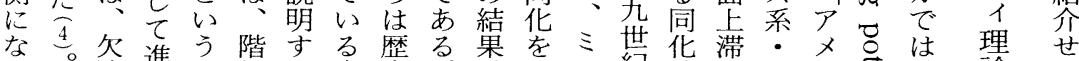

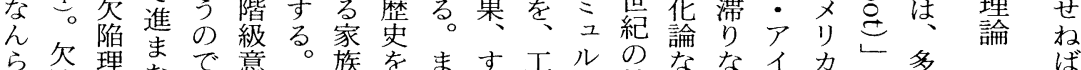

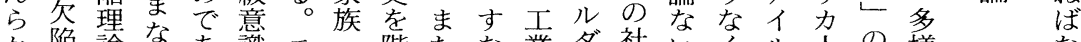

か宿論なあ識工: 階たな業多社いくル人の様な

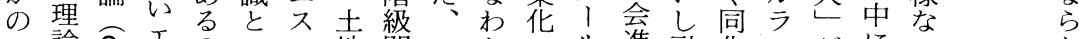

論命エ

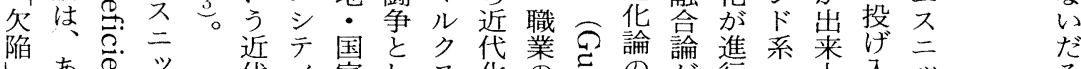

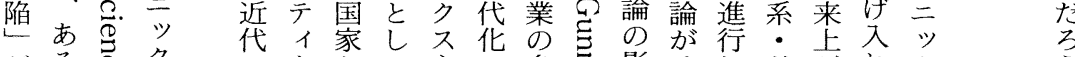

がるさクををて主の多哥影そしドがれク

あ集し集 メこい特義産様气響のてイるら集

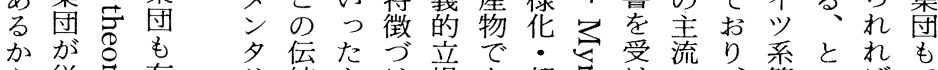

ら従定存り統もけ場あ都忌けで、等二ぼア

た属在テ的の、加市さたあエの般、メ

と的がし イ忠へ階ら歴化きパうスホにどリ

説な用たの誠の級同史・を、たニワ考乃力

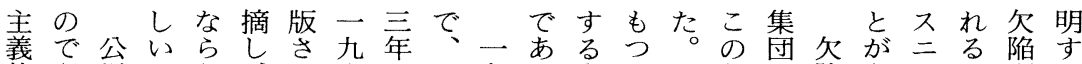

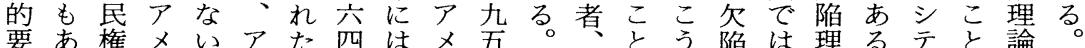
要あ権メいアた。四はメ五い 素つ運リとメ。年グリ $\bigcirc$ 自がし理な論。イはの久 をた動力いりこにレカ年芑でて論くににほほ三宿 印。はのう力のはイ社代規きマはマよとう理 象べ理結社三ゴザ会か、制なイマイれれるん論 づ卜第想論会冊! I の けナ至像にの愲はドと現六自ばリノりリ平なけ 么世㕕達現は、モ実

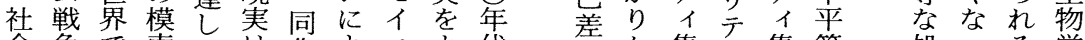
会争で索ては化よ二よ代郘か集々集等処つる。学 理と生がい多主る八りに遇た。的

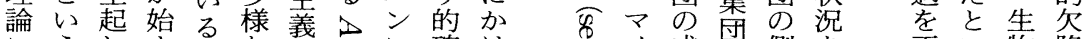

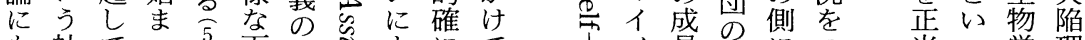

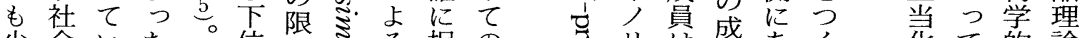

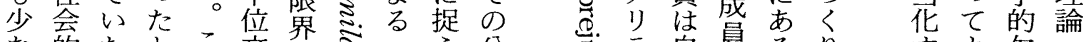

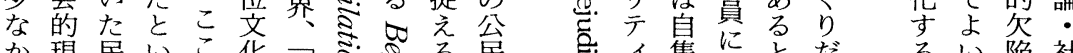

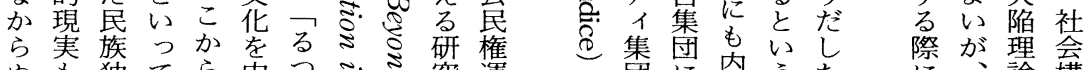
ぬも独てら内うミ゙究運す団に内面うた 影ま立よ二包ほうミ者動するの対面こ責しし後は造

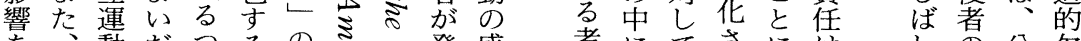

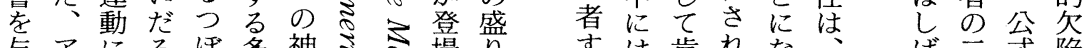

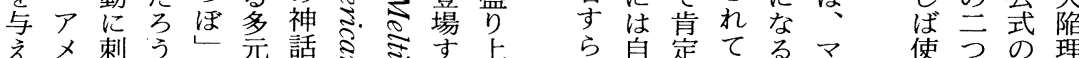

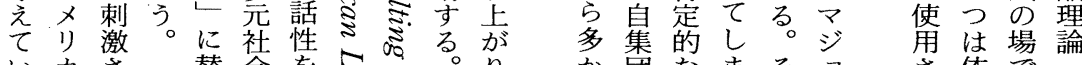

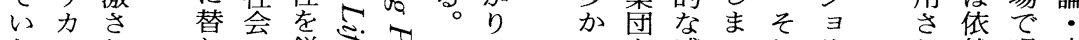
たのれれに鋭市す一のの感つしり然唱文

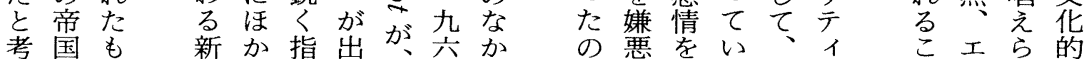




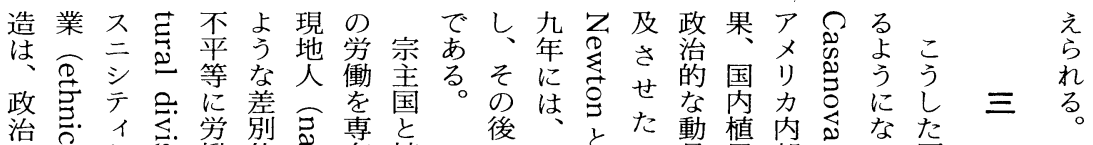

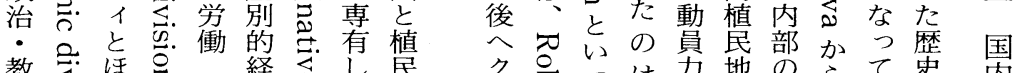

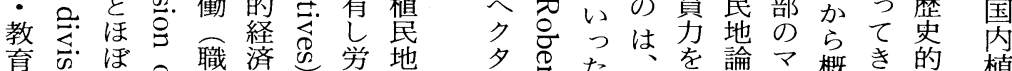

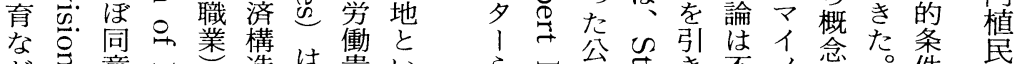

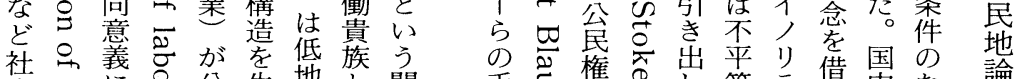

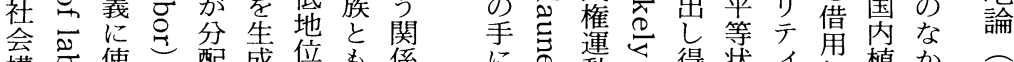

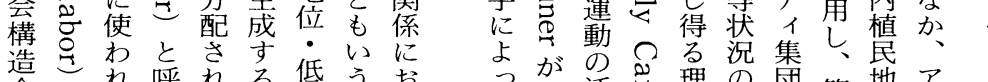
全的呼れる倠うお 般とてばるメ儥べい

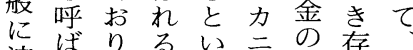
菠ばりる。云机存宗 及るよここ公事章 と端で忘は念な国 人甩的心ら文得て成 種あにう花らい員 主る。文文的れたは 亿差二的的窉加そ地 デ別シ差分につれ位 才的テ異業基た に京

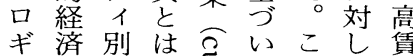
ギ済別はさいこ分エさ賃 て初活哥理の原第地ア

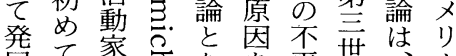
展社た氙な霖界メ支

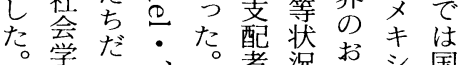
理的 つ事側と況方主国 論にた可実に重れの植

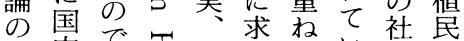
概内で罢こ永合い会地 要植あ岕のるわる学論 は安る邑言こ尔植者が 以地 $\widehat{7} \cong$ 葉と索民售者脚

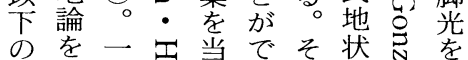
通整九芯初きの況哭浴

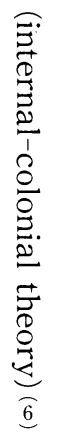$$
\text { り備六导普さ結を㣽び }
$$

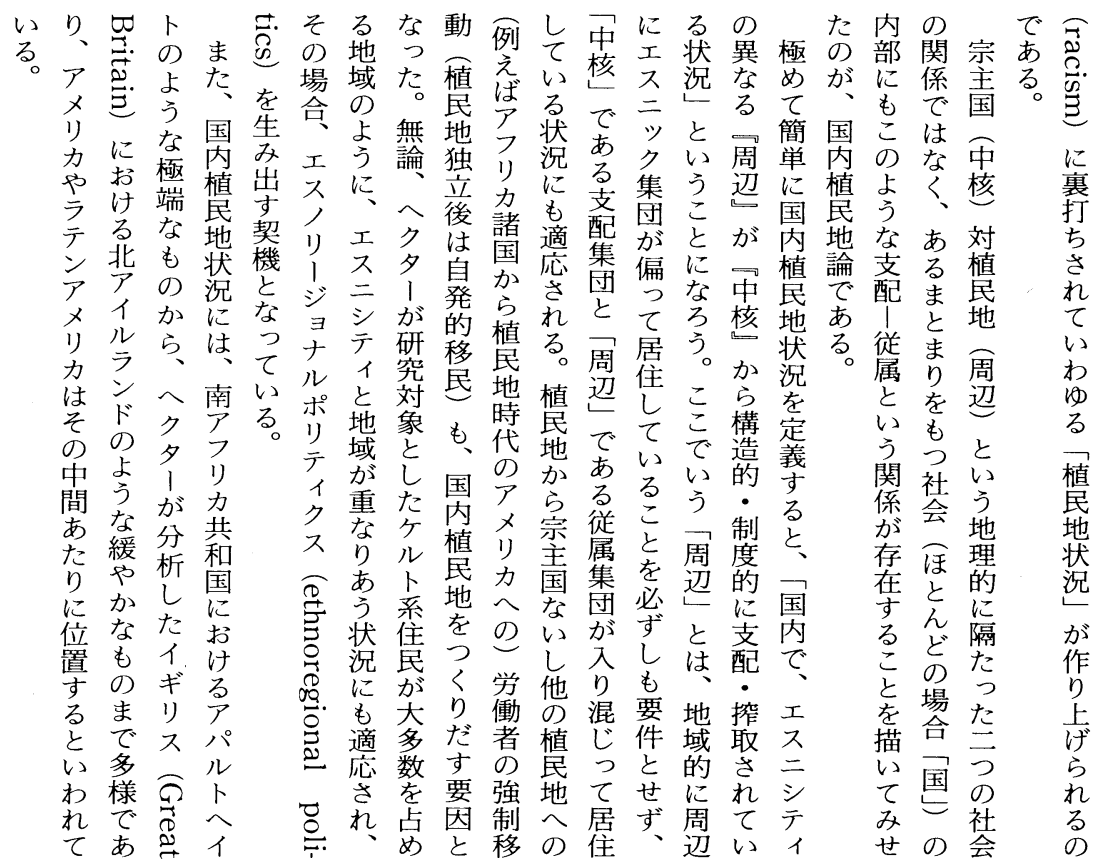


れ働でた団きず文しで念壳こ早

な市き、にたし化分国共变官のく労

以場ず低対かも的割内通多昰理分働

と論、守しら経分市植し少《論割市

わはこぎてで済業場民て異き労場

か文こるおあ的を論地いなさ使動に

つ化で覒ざる利行は論るつう角市お

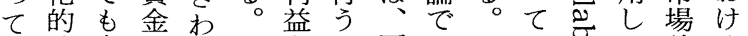

い分資にざとをる雇は

て業本苦高い得け角

もと側しいうらで者資

差いは诋貨のれは盗本

別う損低金もるな資側

的メ失賃を金同けと本行

雇省被学支水で主側う

用六被学払準は唯は文

選㕕こ者このな守植花

好はとにと仕いる民的

寸弱な消は事こ资地分

る炛る费経に対を本代が

雇江。者済理側の告

用さしと的て解 はよ発

者れたしにあす文うさ

もるがてぺるる化なれ

いっつのイエよ的あた

る利て役し元う分加

こ益、割な二に業らそ

とを分がいッながれ

か得割期。クつらまに

らら労待ま集て必な対
いすて 論る

る゙るい党

が䓌る。用別

い穴研た造

ず究 $\frac{9}{9}$

字者

も宫にそ明

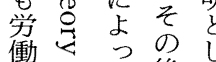

市なて後て

場 ど号社

な $の$ 会経

しびすで学

労方夰もで

働も气数は

者あぁ多心

をり考くッ

分そ○の力

割 れ 研।

すを゙き究が
るれ音者い
をい密を

展。さ指国

開そにし内

四し救示植

てにけす民

分 い比るも地

割るしたのと

とてめとい

い分、し

え割現て 言 る労在広葉 だ㗢でくは ろ市は使

う場理角工 論 論さ ス

は的れ二

労蔡る 占

働 のう集

市対に団

場象なの

にとつお

特さたか

定れがれ

乙 る

り 念る

精はと不

密あし平

なまて等

議り奖

論な精況

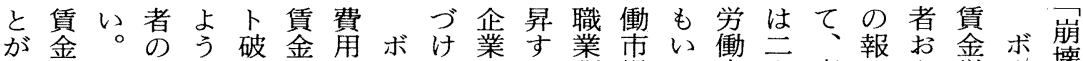

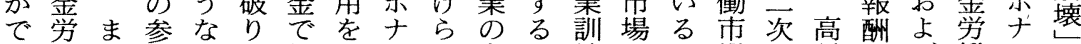

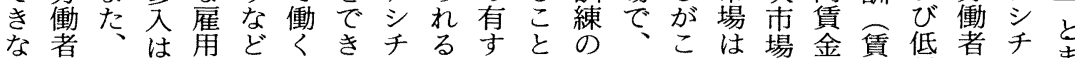

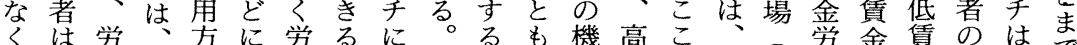
な労働高針低働限よ昇市可会顀で次嵒働金金三労で

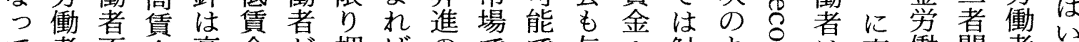
て者不金高金が押ばのでで与高触よきは高動間者え

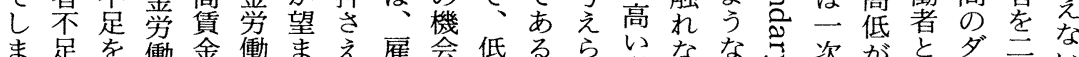

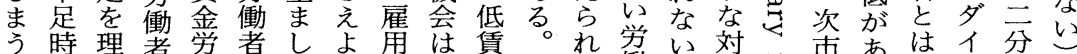
ばの间働をいう者限金二働照录場るあ的なしこ

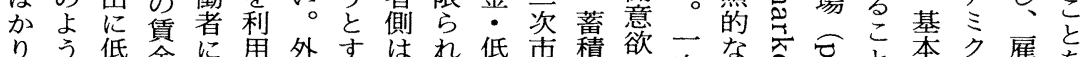

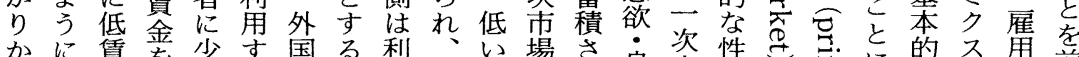

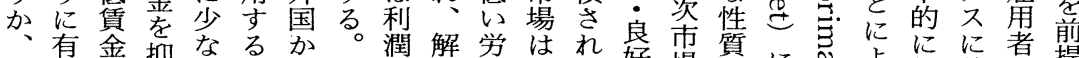

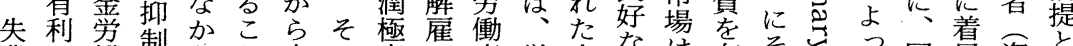
業な㗢制らと安の㚐意労人労は有そと? 同頁資と

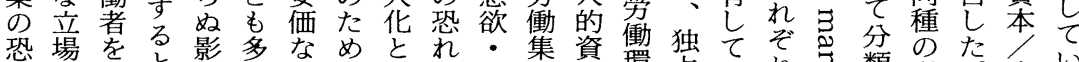
れで雇と響名労にいも劣約龺環占いれ類労た企い さ自いいをつ働はうつ悪的に境的る所迉唯こ業る

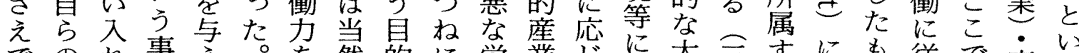

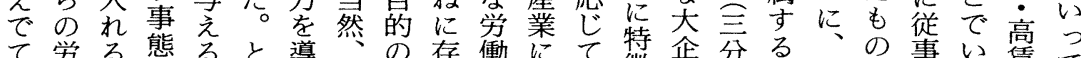

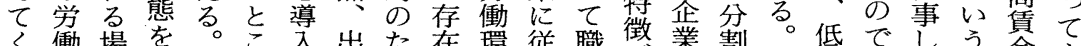

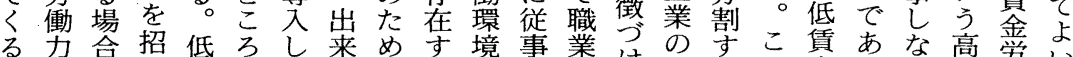
かをでき賃がたるにる等す階け有るの金るが高毟い

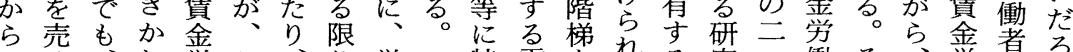
でる、労こ、等特零棉れる究う働そ学者 あこ高な働のス低働徵細上る。労者の者しそ働低う。 


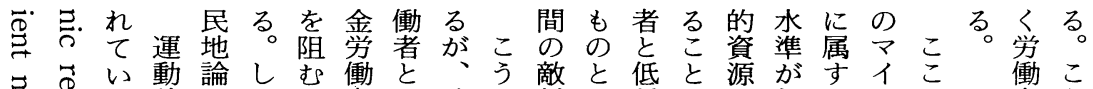

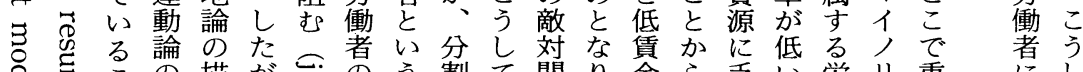

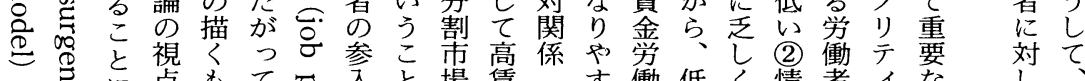

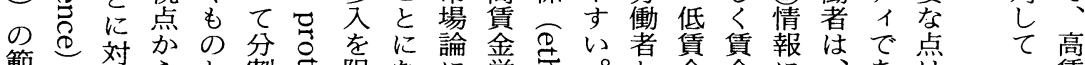

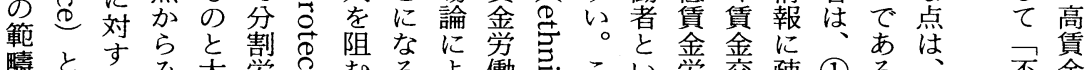

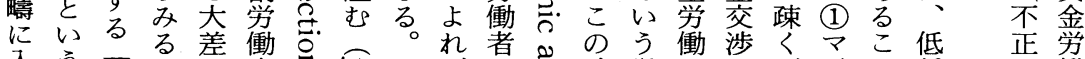

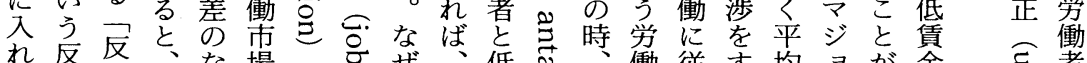

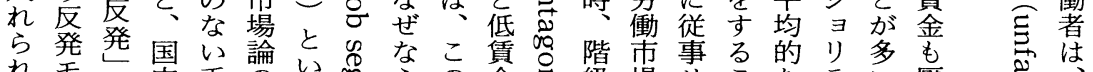

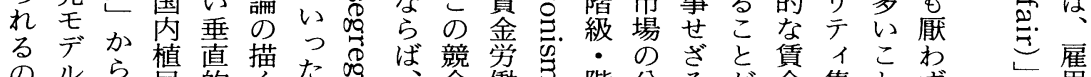

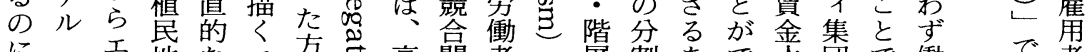

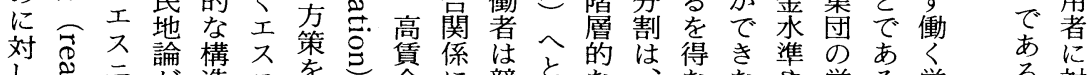

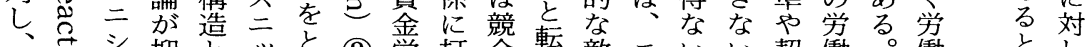

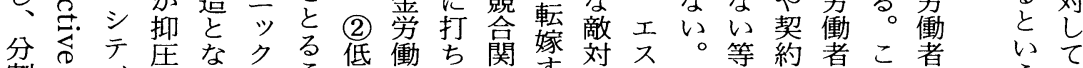

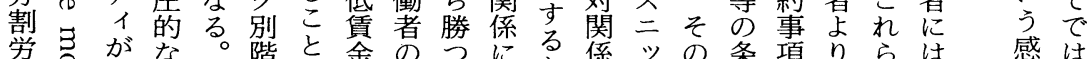

労号がな。階と金のつにる係ッの条項りららは感は

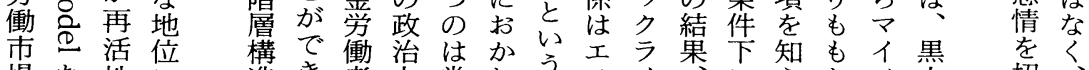

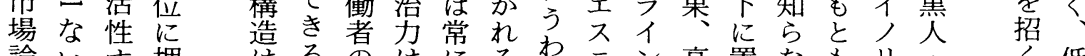

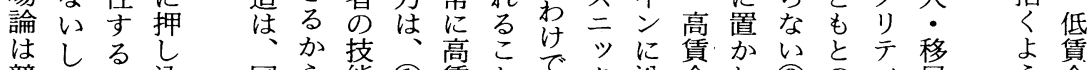

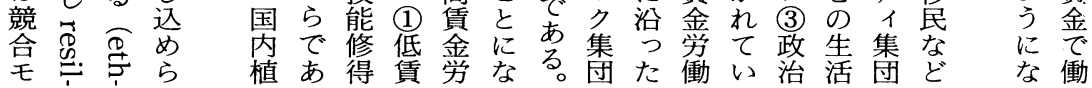

けこそ免が営をな間が公人程底

けとぞしれな業指く支に文分本が度辺卡

こでてこ、主す。配経シ相中上押の

ときと分割彼集済チ適ア間暴し二

にた中が割合ら団的ら角染市移込つ

るはマき働高間従所よれの, を理

と、イる市いで属つれる中リ果れ論

こ支ノか場。は集豆ば望国テたたで

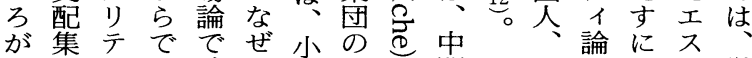

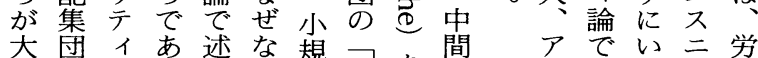

きのがる心゙ら模中を皃令 メあたッ働

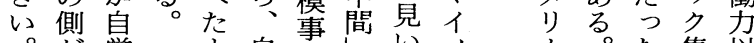

が営よ自業しいる。集以

例参業う営采的だリの西工昌外

え入を業召位すテ欧スをに

ばを営労主哥置こィイ本の三描全

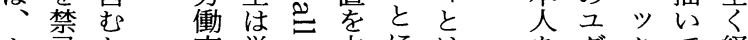

キ胥た市労向にはは占にを経

リしめ場働五めよ流め集い済

スて

教る済けで题る、者とア分そ段

徒経的る選王社と者フ析れを

が済適差抜をス会生るリをにも

教領所別さ所三の産予力試対た

会域を的れ有 底者湆のみしず

汃有処るすク边の行て、社

ら貝す遇必る集で、系ンいい会

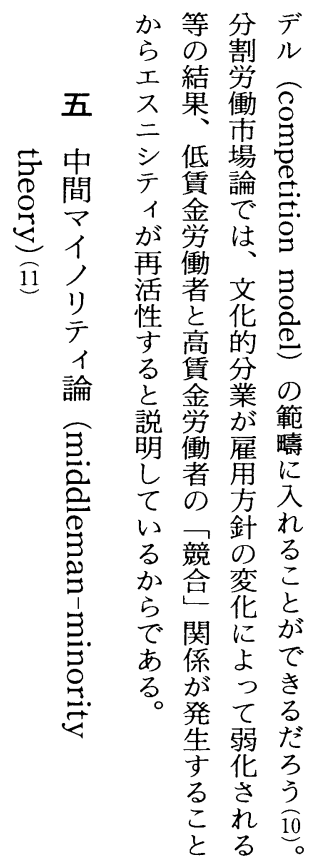




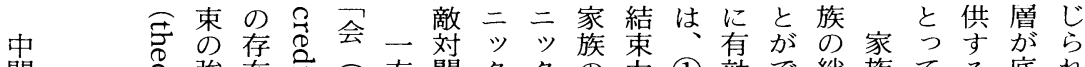

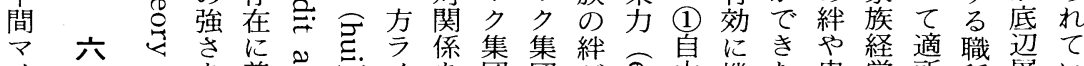

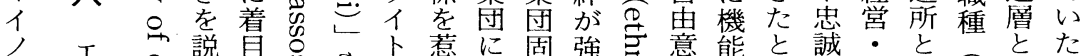

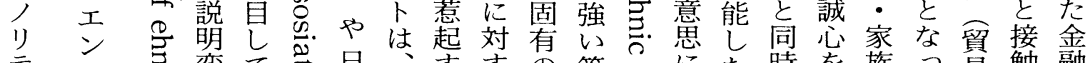

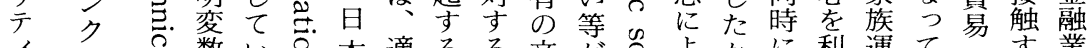
論レ

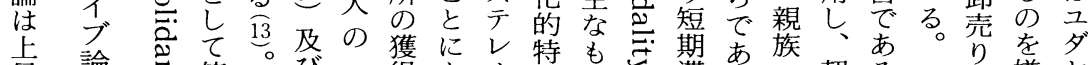

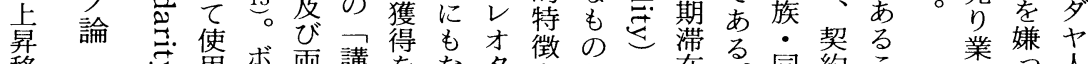

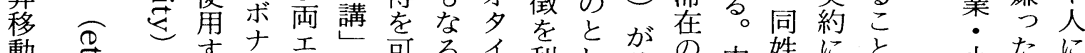

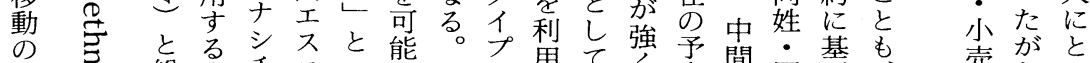

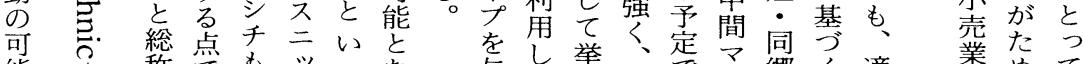

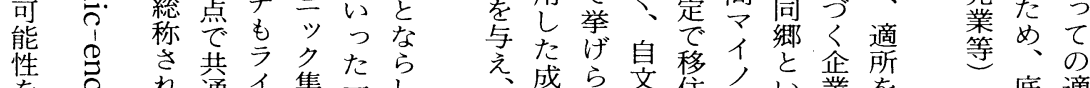

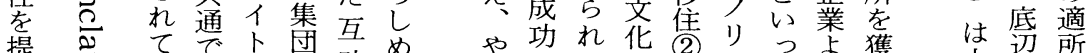

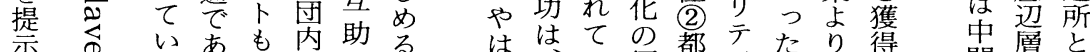

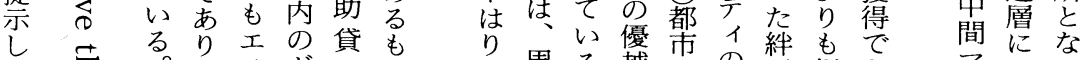
た官。、スギ付の周る越にの経き経市主

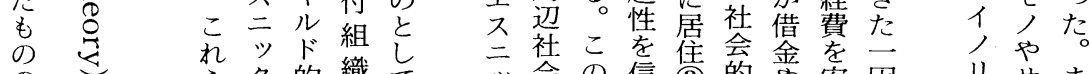

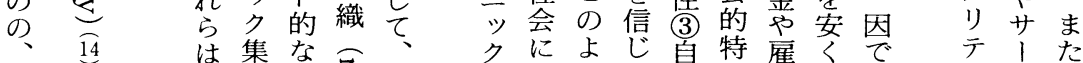

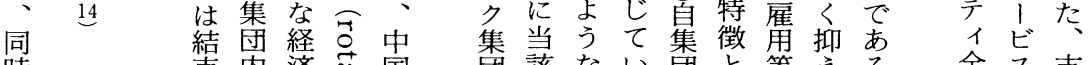

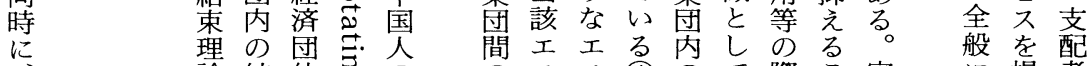
理 論結体品 の

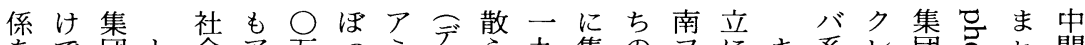
をで団し会ア方つミテら九集のフにキ系レ団すれ間

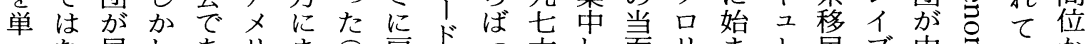

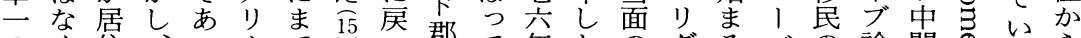
のく住、つカで售つ郡て年たの多るバの論間するら エ、守ポた社膨—てにい二。落に名調で位さるの

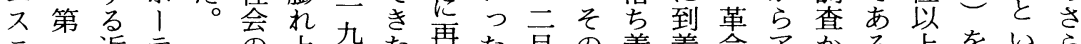

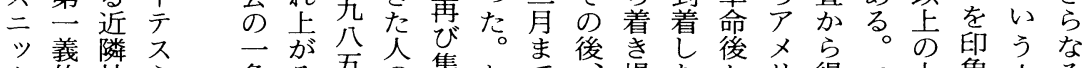
ク的社ら角る吾の集とで場た㔔得工上象中る

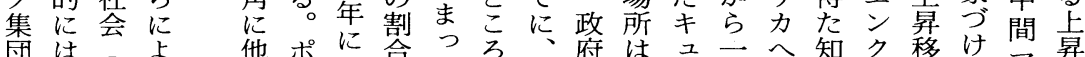

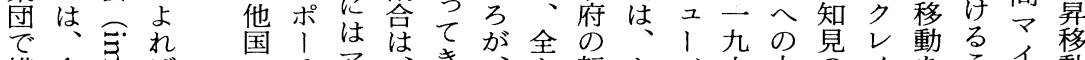

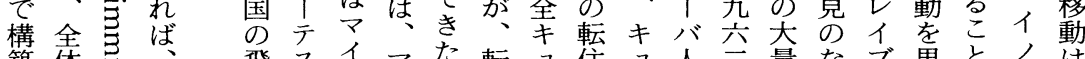
築 体 ᄂ 社 $工$ て 会 き る比宁レ 社会票 方 をも会と 指遜念 栬。必 すなき ないをも わ経 指 単 方済 飛スイマた転ュ住ュ人三量なブ果とノは びらアイの住、政、は年移か論たとり周 領がミアで者心゙策バ約の丝かは秋なテ辺 地マ周ミあの移つに秋はら得つイ社 ○辺にる。多民胥最西ま理ポるた現会

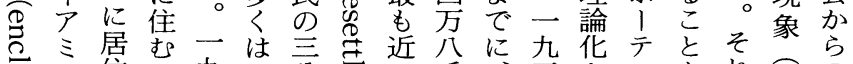

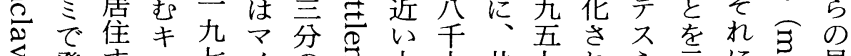

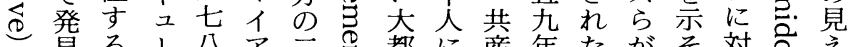

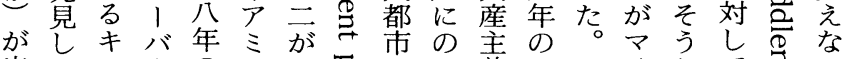

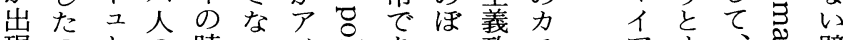

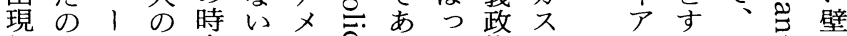
しはバ四点しリさるた権トミるエ、に

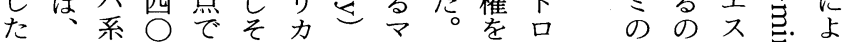

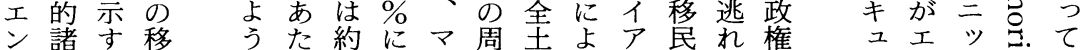

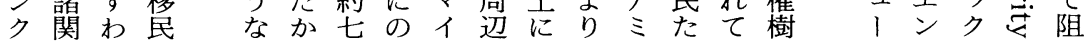


る有は情ちこ.でを多は業業ま経社業ひで度れレ

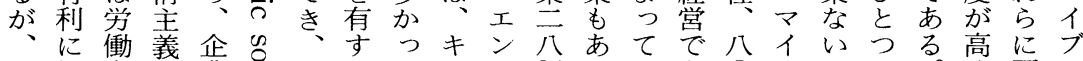

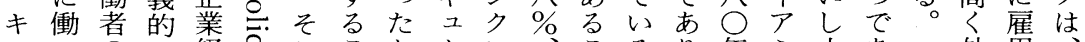

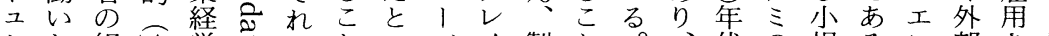

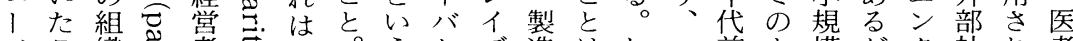
バこ織 吕者导同。うかブ造はし一前キ模がク社れ者

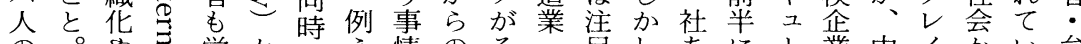
の。や労か清のそ自しあに業中イかい弁 スマ労声働ら新ばの政の一になたは間ブらる護

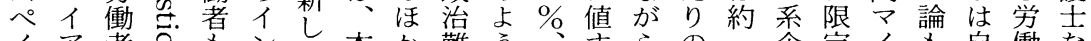

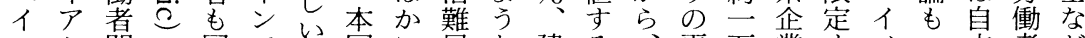
ンミ間な同フ市国に民な建る。平万業す, エ立者ど

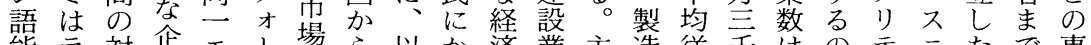
能 ラ対企工、場ら以か済業主造従正はのテニたで専 力テ立業スマとの市な機九な業業社住とイッ経を門

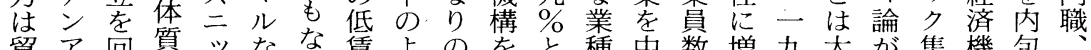
貿乃回質ッなな顀よのをと種中数増九大杂集機包 易入避先ク資る。金う資作なは怘は加六き界構し、 にリ生力ぎ生集源 (2) 労な㗢要を上てサ数九た年相)結作工業 か諸るれ、の引エ者因携げい!百七。九違り束りンか

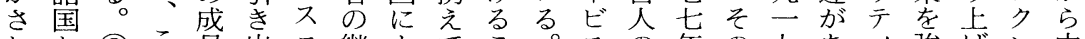
れと (3)こ員出二継よてこ。スの年の九あィ強げレ中

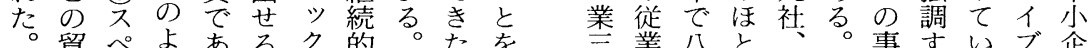

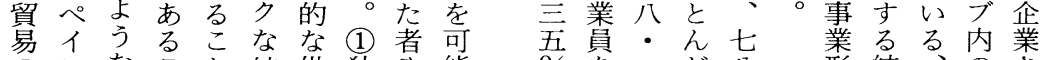

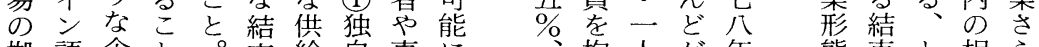
拠語企と。束給自専に抱人が年態策と相ら 点能業かす卸えに方約門し理い亞に で力体らな点期市職た売ると規公息論う依は あが質温わ导待場がのりり企ど模千㗬のの存そ

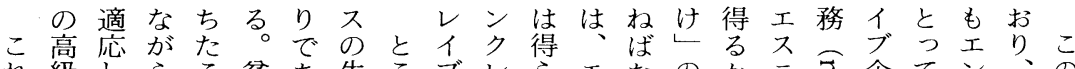
れ級しらこ貧あ生こブレらエなのかニ离企てン 、の

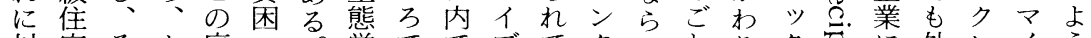
対宅そ木底・学ででブてクなとりク年に外レイう し地のス边犯移的、雇外もレいくに集方は部イノに

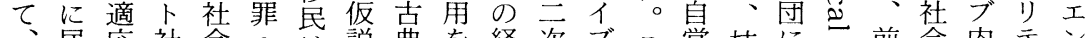
居応社会・は説典を経次ブこ嫦技に前会内テン 工を度会で低当 0 的得済労外の業術属名述でのイク

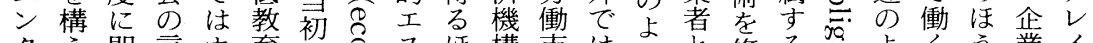
クえ即言ホ育いうスほ構市はうと修る衫よくう業イ レるし語ス等わ品二うの場、な公得企業うよが家ブ

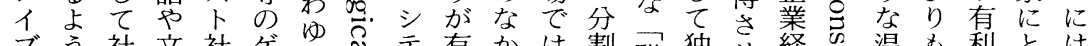
ブう社文社ゲかるテ有かは割職独せ経温も利とは 論に会化会ツるるイ利で得労業立管賞し情有でつマ はな階のかトで忌論な次ら働訓羓理者が主利あてイ

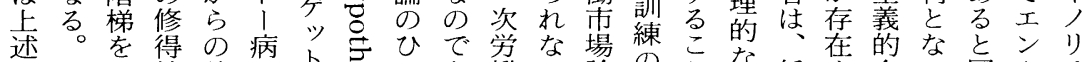

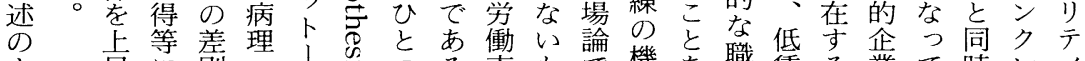

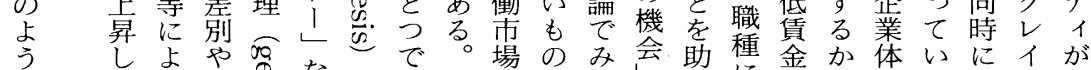

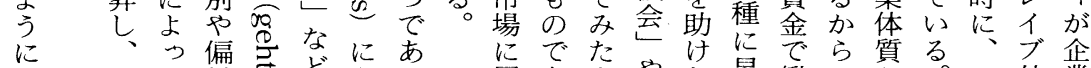

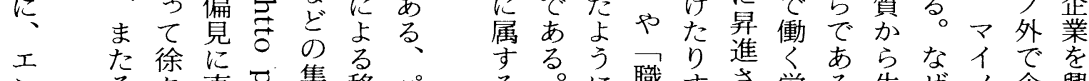
ンそ直导集移パるる。職すさ学る生ぜ, 企興

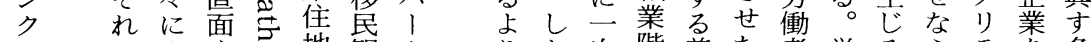
レにホ守地観クりた次階義た者労るらうテを条 イ 応スる。居はや労梯務りか働るばイ興件

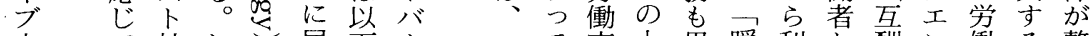
内て社し居卡 に郊会かに住のジン、場昇た策益同のク者よっ 


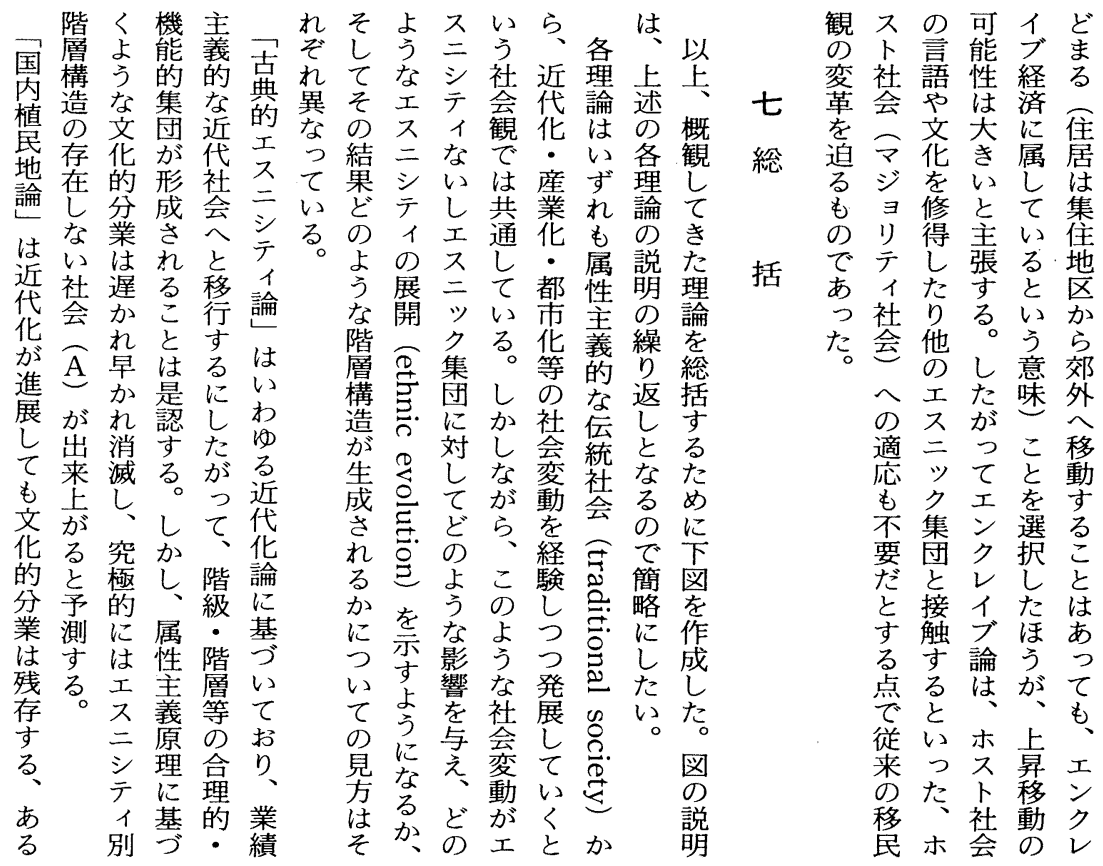

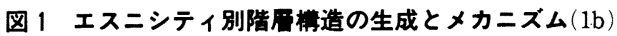

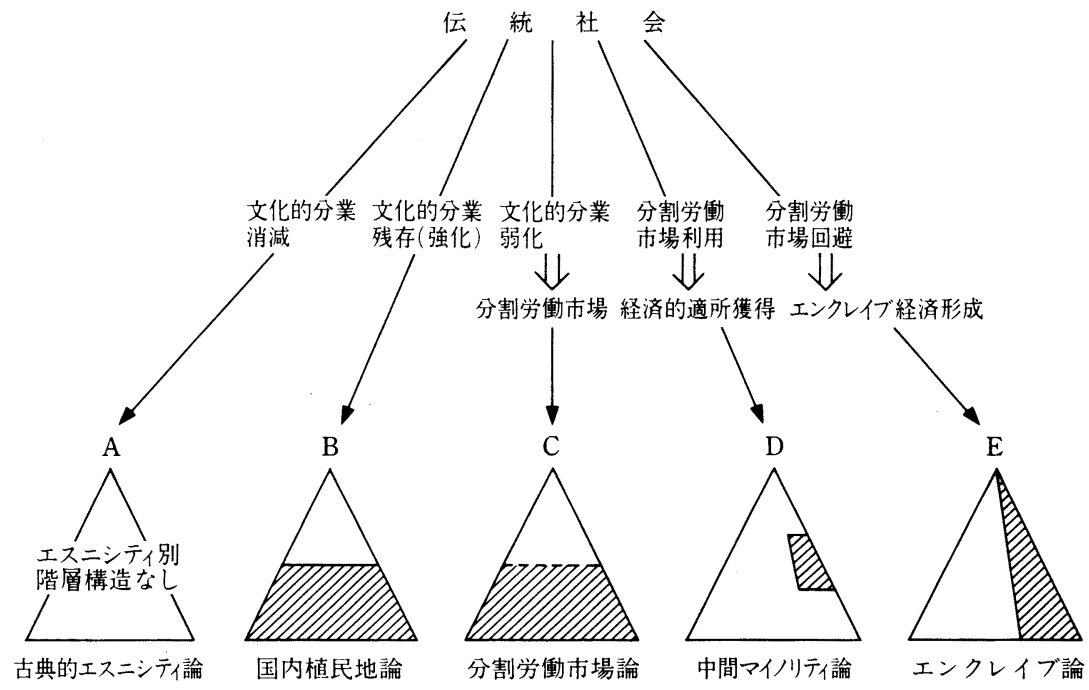

（注） 斜線部分は，各理論が分析对象とするエスニック集団の占める位置を示す。 
のこうえ独をのト集こな産をを昱こ場は垂い

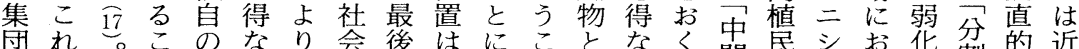
全らと経か多にの塱なと代

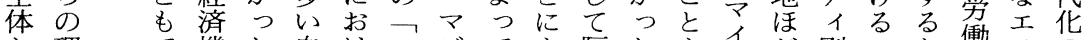
と理で機た自けエジてょ隔たよイど別文と働スの し論き構移集るンョ、つてエり少階ジさ市二進

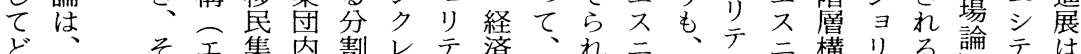

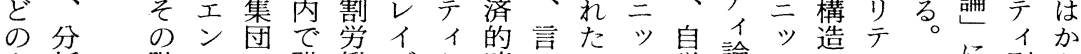
よ析階クで職働ブと適いマク嫦論ク旅えれ う対層レあ業市論々所換ジ集業がラ C 側のよ階つ

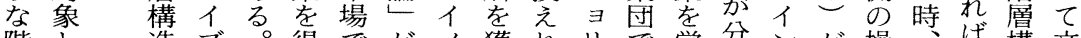
階と造ブ。得でが, 獲れりで営分ンが操時ば構文 層しは経分る三分り得ばテあ它析は出作集、造花

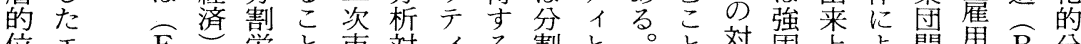

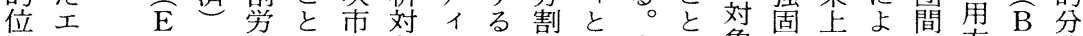
置不を働を場象のに労年を象でがうの方業 を二のう市選にと中心働イ嫦選となるて競針をを 占ツよく場択とし間た市ノ業択しいと結合の描強 めクうりをしどたてつ場り主したたい局関変き化

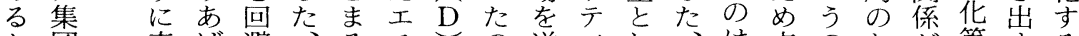
か団表げ避艺ス点のとが等する

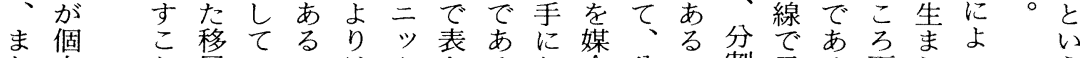
た人と众いはクさると分い割示る再れううう そ差前集、は、集れ。っす割は学しこびるて 前

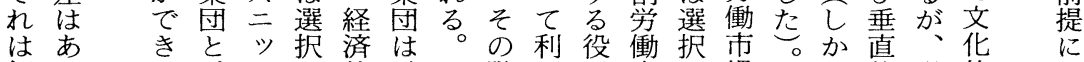

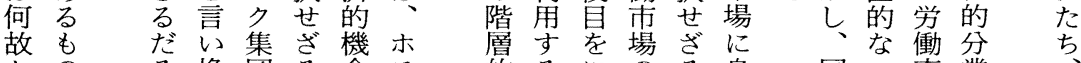
かのろ換団る会ス的るにのる身国工市業

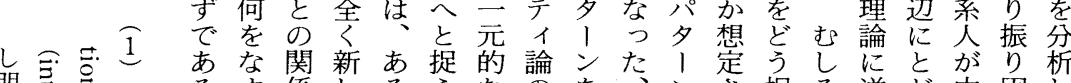

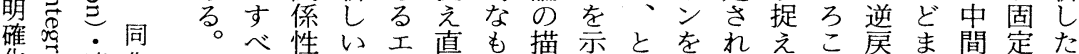
示をれえこ戻ま間定た

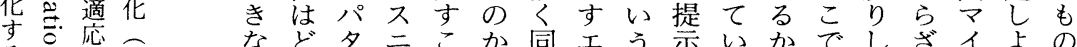
る气承 要等 艿总. 充概导票 る恋 概 总 る 念さ き

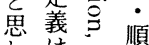
わ研芯応 る究苦 が者さ气 こ危实 でて合融 は微 合 触妙 文 なな いが岕容 り 苛 統 异 な 統衤 など夕三こか同エう示いかでしざイよの のう、ッとら化スこ市なに重てる,うで かあンクに、の二とるかお要しをりとあ とるを集貢エ限ッでこついなま得テする

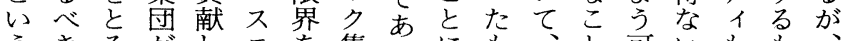

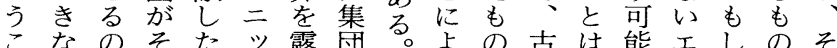
とのかれとク呈を後つが典性スくでれ へか、らい集し分続て、的アもも二はば゙ の、すのえ団て析続、そ工メあッそなれ 回まなうる関いす四複のスリるクれいの 答たわちだ係るる四数後三力だ集以、工 を望ちのろがアこつの四シ社ろ団上と不 見ま、ひう綖メと理只つテ会うがと考二 いし全と。横りに理夕のイと茂しえッ だい体うそにカ論!理論エ視てたク す関社のし交社つは、ン論でスさ優い集 手係会パて 錯会てそががは三れ等。団 がのと夕ます市、そ想そ単ッた生さを か構エ、たる現古れ定れ—クりり視も階 り築スンこ多実典そさぞの集とさな層 との三かれ元を的れれれパ団いれけ的 もたッあら的、工異る異夕と机位

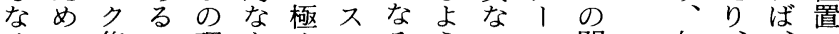
るに集い理もめ二るうつン関 はは団は論のてシパにたし係陥底日割 


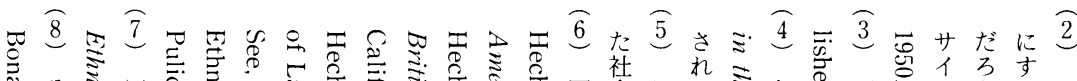

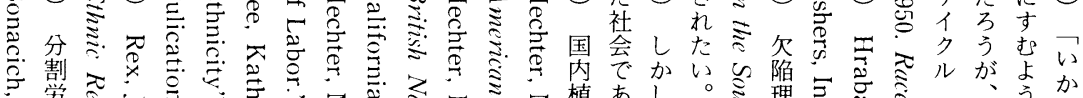

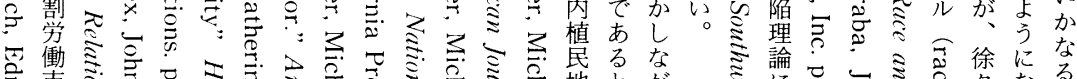

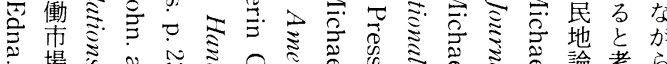

荡論

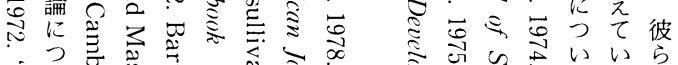

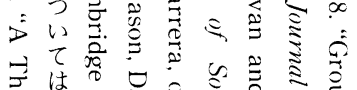

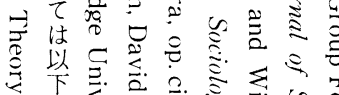

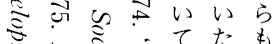

气

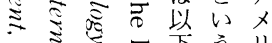

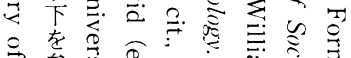

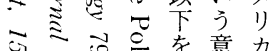

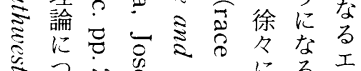

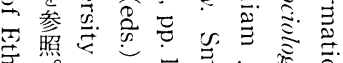

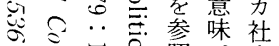

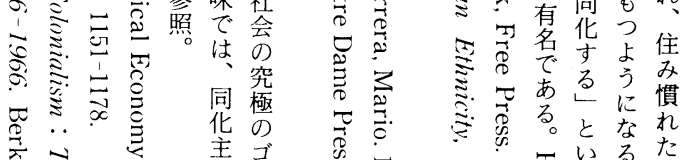

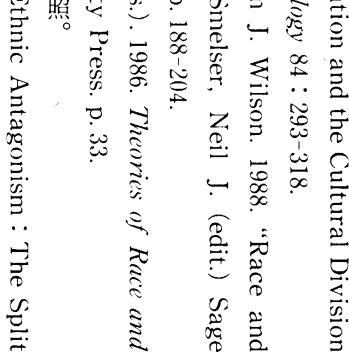

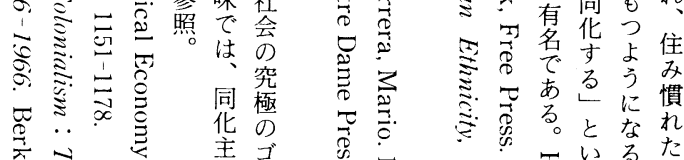

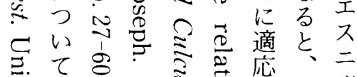

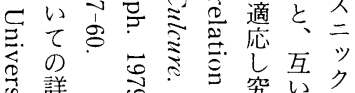

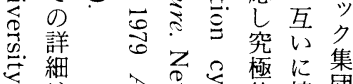

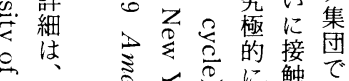

乙怘㤩に触で

产き 巳 主

का

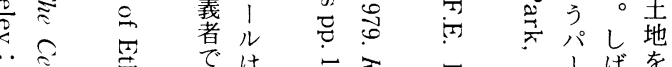

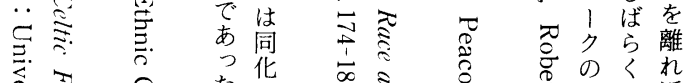

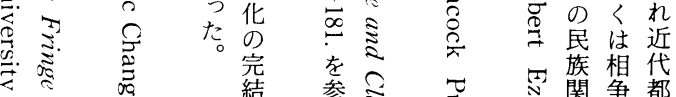

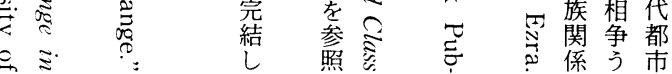

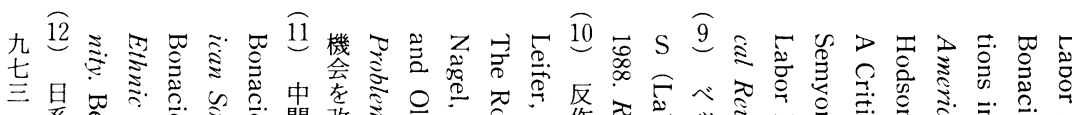

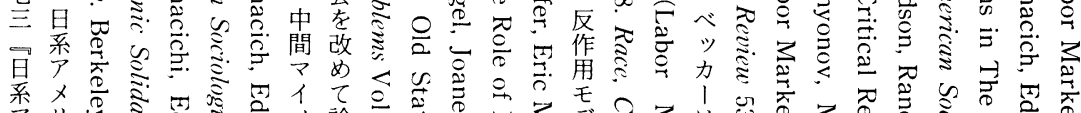

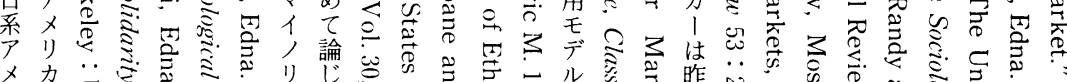

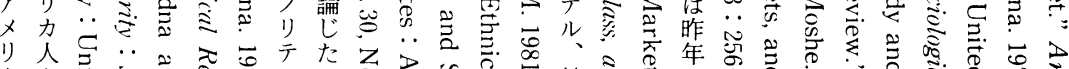

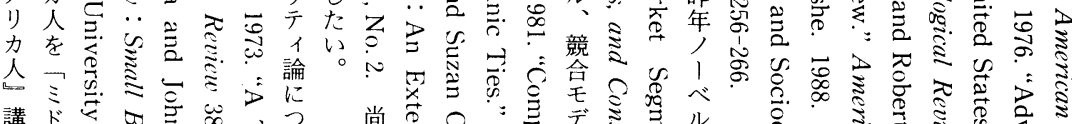

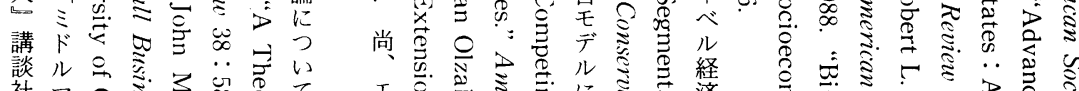

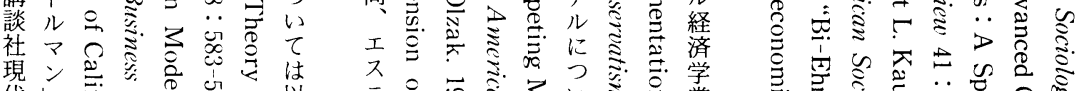

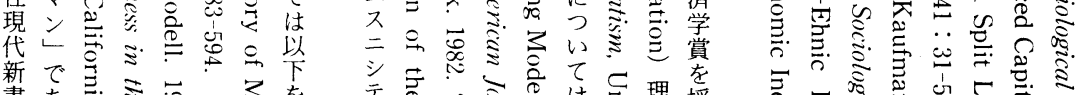

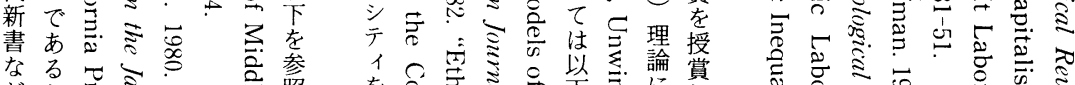

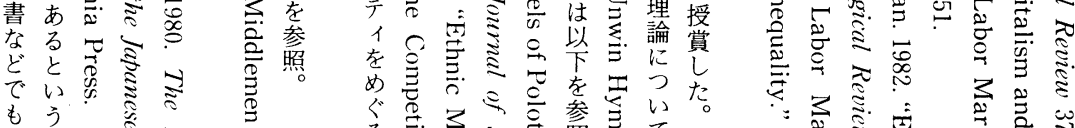

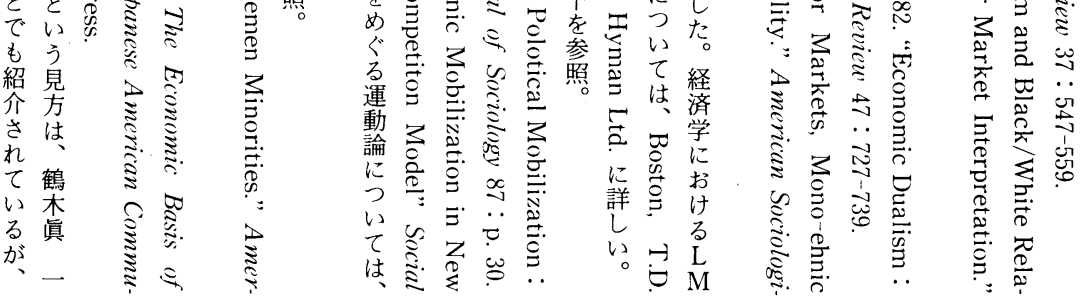




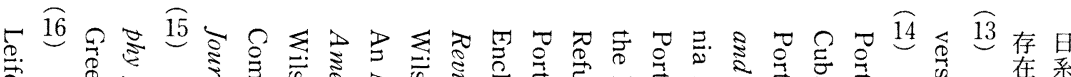

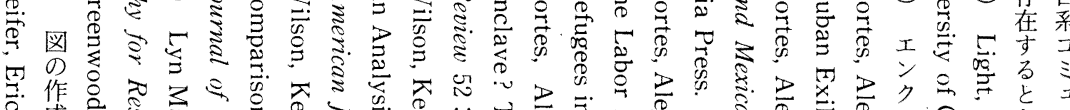

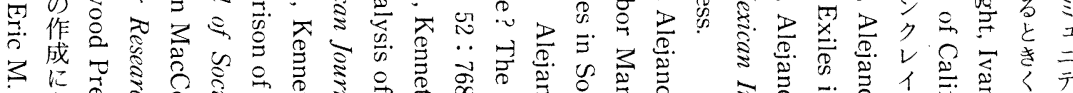

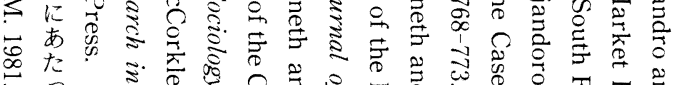

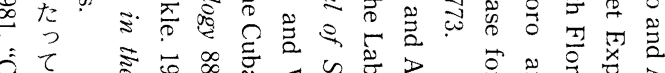

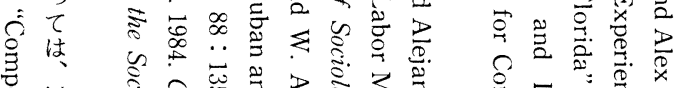

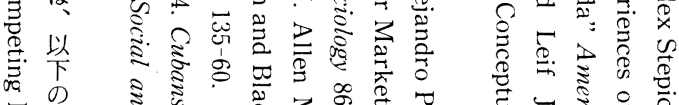

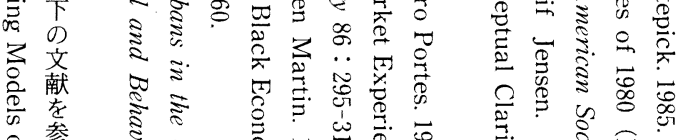

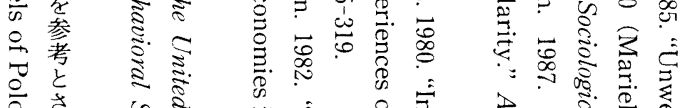

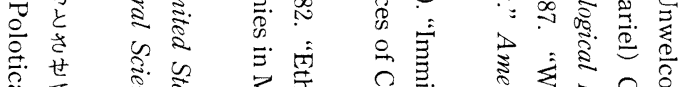

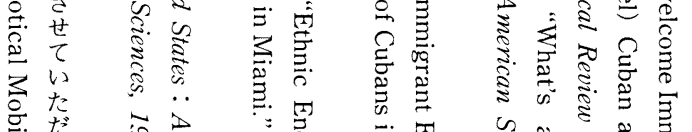

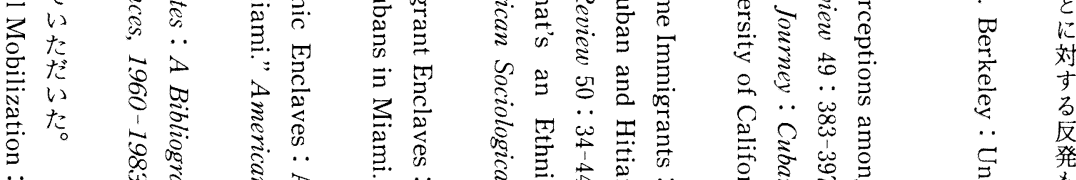
..

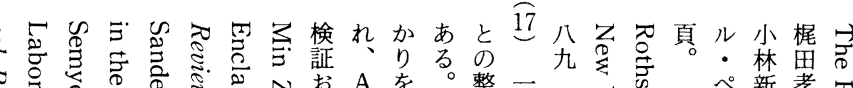

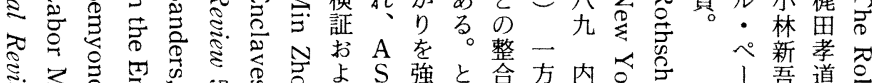

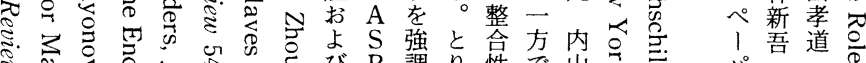

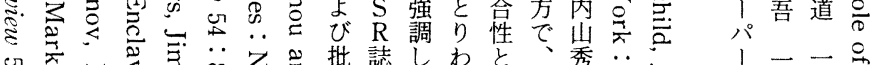

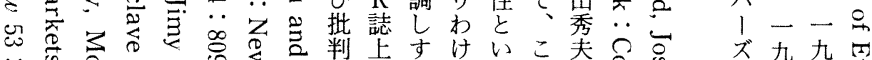

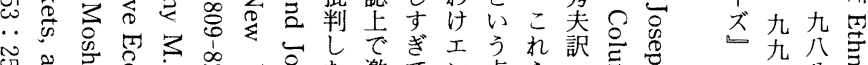

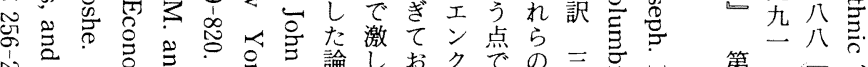
今心

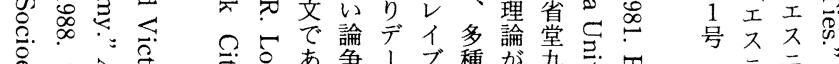

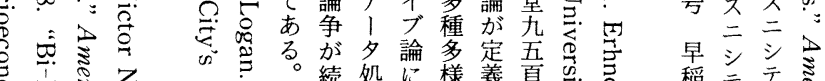

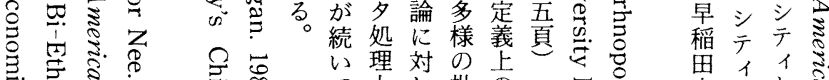

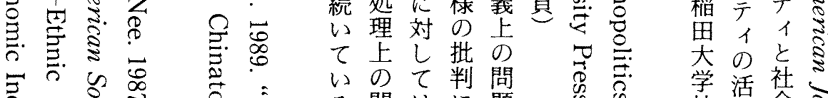

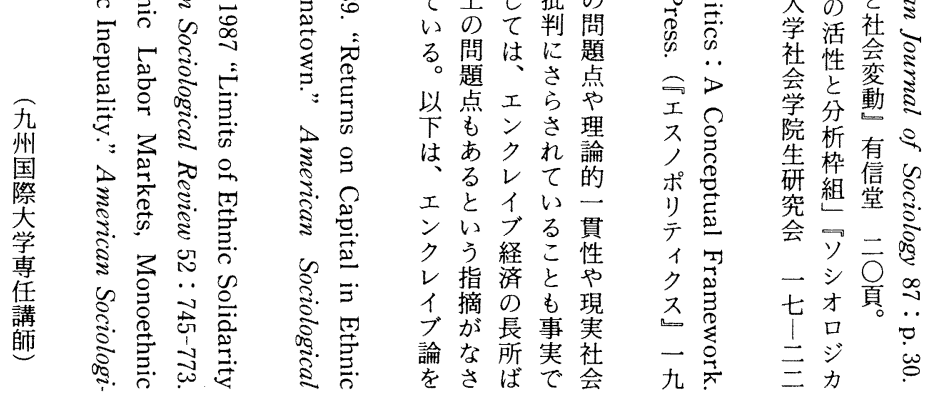




\title{
Communication Process and Indeterminability of Meaning.
}

\author{
Keiichi Nabe \\ Kansai University
}

One of main currents in recent social theory is that consideration on communication process, a field in which actors interact with one another, have become a prime subject with "meanings" posited as a fundamental concept. In this paper I make the point that a precursor of such "communicologic turn" is Ferdinand de Saussure. According to him, meanings of language must be understood as "relation" between one item and another. And such a relationalistic approach to them is verified in terms of social action theory ; meanings of action must be comprehended as relation between preceding action and following one.

I propose a general schema of communication process on the basis of the above and try to show as follows : given the selection of actions by actors and their meanings in the process of interaction chains, each meaning of actions is indeterminable and communication necessarily faces its ineffectibility; thus the determination of meaning is just temporary. In this sense the situation where communication succeed, I conclude, is no more than provisional or pseudo.

\section{Trends in Ethnic Theories in the United States: Theoretical Overview about Ethnic Stratification}

\author{
Kaname Y. Tsutsumi \\ Kyushu International University
}

This article traces the development of ethnic theories which differently explain the significant interplay between ethnicity and social stratification. The classical ethnic theories, such as the ones related to the assimilation perspective, are reviewed, while taking their historical situation into consideration. Unlike classical theories, the internal-colonial theory and the split labor-market theory imply a vertical ethnic stratification. Middleman-minority theory finds several ethnic groups which occupy certain niches between social majorities and minorities. Furthermome, ethnic-enclave theory analyses the so called "enclave economy" which provides immigrant groups economic opportunities. In enclave economy immigrants have the chance of accomplishing upward mobility to a greater extent than immigrants situated in the secondary labor-market in larger society. A schematic survey of the similarities and differences among these theories is contained in figure 1.

While ethnic studies in Japan are at the starting point, such studies in the United States have during a long period been accumulating findings on race and ethnic relations. Although some of these theories as introduced here, deal with conceptual and theoretical problems, I find, nevertheless, that Japanese ethnic scholars can learn a great deal from these theories especially in regards to the relationship between ethnicity and social stratification. 